\title{
Pensar o Islão: Questões coloniais, interrogações pós-coloniais
}

Thinking Islam: Colonial issues, postcolonial questions

Penser l'Islam : questions coloniales, interrogations post-coloniales

\section{AbdoolKarim Vakil}

\section{OpenEdition}

\section{Journals}

Edição electrónica

URL: http://journals.openedition.org/rccs/1335

DOI: $10.4000 /$ rccs. 1335

ISSN: $2182-7435$

\section{Editora}

Centro de Estudos Sociais da Universidade de Coimbra

Edição impressa

Data de publição: 1 Outubro 2004

Paginação: 17-52

ISSN: 0254-1106

Refêrencia eletrónica

AbdoolKarim Vakil, «Pensar o Islão: Questões coloniais, interrogações pós-coloniais », Revista Crítica de Ciências Sociais [Online], 69 | 2004, colocado online no dia 01 outubro 2012, criado a 04 maio 2019. URL : http://journals.openedition.org/rccs/1335; DOI : 10.4000/rccs.1335 


\section{ABDOOLKARIM VAKIL}

\section{Pensar o Islão: Questões coloniais, interrogações pós-coloniais}

O "terrorista islâmico" e os imigrantes e minorias muçulmanas culturalmente "inassimiláveis" representam as duas faces da visão do Islão como "o problema do século XXI" que domina o debate público contemporâneo e a formulação das políticas de Estado nacionais e internacionais nas sociedades ocidentais. A natureza das representações, mais ou menos essencialistas, que informam e deformam estes debates varia consoante os contextos em virtude da relação histórica, em regra colonial, de cada nação com o Islão, das instituições e saberes vocacionados para o seu estudo, e da composição, perfil e peso das comunidades muçulmanas em cada sociedade. Mas a lógica identitária e securitária que configura o discurso do Islão como problema reproduz, redefinidos agora como problemas do multiculturalismo, da governação, da tolerância e da segurança, as mesmas preocupações identitárias e securitárias geradas no contexto colonial. Este artigo apela a uma abordagem desconstrutiva do Islão através da leitura crítica do discurso português.

\section{Introdução}

Comentando as representações e a discussão do Islão nos media americanos no contexto do pós-revolução iraniana e da crise dos reféns da embaixada dos Estados Unidos em Teerão, Edward Said fazia notar:

Actualmente, o Islão é definido negativamente como aquilo com que o Ocidente está em confronto radical e esta tensão cria um quadro de entendimento que limita em extremo o conhecimento do Islão. Enquanto este quadro se mantiver, o Islão, enquanto realidade elementarmente vivida pelos muçulmanos, não poderá ser objecto de conhecimento. (Said, 1981: 155)

Nos três anos decorridos desde o 11 de Setembro, quando novamente se pode repetir, e com mais fundamento ainda, que "virtualmente nada nos estudos sobre o Islão pode hoje dizer-se 'livre' e não determinado por pressões urgentes e imediatas" (ibid.: 135), a observação de Said não poderia ser mais relevante nem o seu sentido mais coerente. 
Com o ataque às Torres Gémeas e ao Pentágono, o terrorismo "islâmico" catapultou "o Islão" para o centro de todos os debates. De referência exótica embrenhada em realidades reconfortantemente distantes, ou presença próxima mas marginal e marginalizadamente irrelevante, o Islão e os muçulmanos impuseram-se à consciência da generalidade da população como a mesma incógnita traduzida na ameaça representada pelas imagens televisivas que deram entrada em todas as salas de estar e espaços públicos pelo mundo fora. $\mathrm{Na}$ ávida procura de resposta a perguntas que não sabiam sequer formular, as pessoas deixaram claro onde as iam procurar: em Portugal, os livreiros anunciaram que se tinham esgotado os exemplares do Corão à venda, e nas universidades, cujo ano lectivo abriu poucas semanas após, as cadeiras de língua árabe ficaram superlotadas. Na ausência de especialistas com conhecimento de primeira mão dos contextos políticos, sociológicos, económicos, culturais, ou sequer religiosos, do mundo islâmico ou do Islão contemporâneo, a procura dos media gerou alguns autodidactas formados pela cartilha, apressadamente aprendida, de Bernard Lewis, e cuja autoridade se foi legitimando à força da repetição incontestada de generalizações reconfortantemente simplistas.

$\mathrm{Na}$ discussão sobre o Islão que se seguiu, e ao longo destes três anos da "Guerra contra o Terror", as questões e "debates" que têm predominado nos media æ a respeito da indiferenciação do temporal e do religioso, da irreconciliabilidade da democracia, do anti-modernismo, da irracionalidade político-religiosa, da violência congénita e da subjugação e escravidão da mulher æ vêm-se construindo em torno dos mesmos tópicos da retórica e polémica anti-islâmica, e com o mesmo essencialismo redutor e orientalista, que caracterizam o discurso sobre o Islão no Ocidente desde o Iluminismo. Ao mesmo tempo e pelo mesmo compasso que a tese da decadência e do ressentimento islâmico se vai consensualizando, vai-se confirmando a superioridade de um Ocidente que, temporariamente abalado pelos desafios do pós-colonialismo e do multiculturalismo, de novo se afirma orgulhosamente exportador dos valores humanos universais. O discurso da modernidade (ocidental), construído pela universalização de um percurso histórico específico (aliás múltiplo e diferenciado nas várias sociedades europeias e americana) cuja historicidade apaga, projecta como futuro único um mundo globalizado moldado à sua imagem, desqualificando como tradição ou reacção as vias alternativas de (trans)modernidades (Sardar, 2004c) não ocidentais.

O mesmo orientalismo que essencializa o Islão fundamenta a ontologização do Ocidente. Nestes termos, e de dentro da pobreza conceptual desta visão a preto e branco de um triunfalismo ocidental cego e ensimesmado, não só fica excluída a possibilidade de apreender o Islão como realidade 
significante vivida pelos próprios muçulmanos a que Said se referia, como não são nem conhecidos nem concebíveis os múltiplos e vigorosos debates, propostas e polémicas que espelham as diversidades nacionais e intra-nacionais, e as fracturas, diálogos e articulações transnacionais que constituem a pluralidade do Islão contemporâneo e se projectam na re-imaginação de futuros islâmicos alternativos (Sardar, 1991; Inayatullah e Boxwell, 2003). A imputação simplista da teocracia islâmica, esbatendo a própria diversidade de percursos históricos, compromissos e soluções da relação Estado-Igreja no Ocidente, e cega às expressões de religiosidade pública dos contextos não ocidentais em que vive a larga maioria das populações do globo, não apenas ignora os debates sobre os sentidos "islâmicos" e a realidade histórica da relação entre política e religião (Ayub, 1991: 5; Asad, 1993: 200-236, 2003; Ramadan, 2004: 144-147) como as próprias propostas de "secularismo islâmico" (Ezzat e Abdalla, 2004). A recusa em reconhecer a racionalidade (e a pluralidade) de mobilizações políticas islamistas, esconjuradas e indiscriminadamente etiquetadas "fundamentalistas" e "terroristas" (Euben, 1999; Sayyid, no prelo) não só cega os que delas se servem acriticamente frente a expressões legitimas de formas de contestação e oposição políticas populares como os torna cúmplices das políticas de Estado repressivas e anti-democráticas (Abu-Rabi', 2004a); exactamente do mesmo modo que a definição estreita e inflexível de um feminismo ocidental hegemónico arvorado em cruzada se mostra incapaz de reconhecer a legitimidade de formas de mobilização feminista islâmicas (Fernea, 1998; Ask e Tjomsland, 1998; Badran, 1999; Majid 2000: 99-131; Muñoz, 2002), e se presta até a formas de instrumentalização neo-colonial contra-emancipatórias (Hoodfar, 2001: 422; Eisenstein, 2002; Hirschkind e Mahmood, 2002). Dentro dos parâmetros deste discurso do Ocidente como modernidade, não é possível pensar modernidades islâmicas (Cooper et al., 2000; Mirsepassi, 2000) ou reconhecer contribuições científicas islâmicas para a crise ecológica gerada pelo paradigma da modernidade tecnológica (Ouis, 2003).

Contemporaneamente, o Islão impôs-se pela primeira vez como problema e ameaça com a revolução iraniana. Mas precisamente porque entrava em ruptura com o paradigma da modernização secularizante, a própria definição do "problema" levou algum tempo a ganhar contornos precisos e, de facto, foi numa singularidade do Xiismo mais do que sobre o Islão em si que de início essa leitura incidiu. Com as primeiras manifestações de articulação transnacional da ressurgência política islâmica, e, muito particularmente, com as expressões que essa articulação assumiu entre as comunidades muçulmanas da Europa, com o caso Rushdie primeiro, que pela primeira vez as levou a ensaiar formas de mobilização política nacionais (na 
Inglaterra particularmente), e com a Guerra do Golfo depois, em que essa mobilização passou a ser perspectivada já muito concretamente em termos de quintas colunas, o problema islâmico assumiu os contornos de problema de ameaça externa-interna e de integração política que o 11 de Setembro veio exacerbar e finalmente redefinir sob o prisma do Estado securitário. A batalha mais importante da guerra pelo Islão, segundo Gilles Kepel (2004), é a que será travada ao longo da próxima década nos subúrbios das grandes cidades europeias, e ela será ganha ou perdida em torno da integração dos jovens muçulmanos das comunidades de origem imigrante. Por um lado, a viragem para a direita dos governos populistas, com plataformas eleitorais de anti-imigração e um discurso de nacionalismo cultural em que a integração cada vez mais se define como assimilação, vai também identificando cada vez mais explicitamente os muçulmanos como problema; por outro, o clima de ansiedade e suspeita estimulado pelo discurso securitário duma "Guerra contra o Terror" centrada na ameaça islâmica e no estrangeirismo da cultura e mentalidade muçulmanas vai simultaneamente destituindo os muçulmanos daquele sentimento de paridade de cidadania que precisamente constituiria o fundamento de políticas de integração igualitárias e culturalmente dignificantes. Neste clima político e securitário centrado no Islão e nos muçulmanos como "problema", mais uma vez, como quando das guerras de pacificação de populações coloniais muçulmanas e da sua governação pelas potências europeias, se apela ao fomento dos estudos islâmicos aplicados (em Portugal: Margarido, 2003; Moreira, 2004); e mais uma vez, para citar de novo Said, o problema estará menos no Islão do que no seu enquadramento como problema. O verdadeiro passo para o compreensão do Islão é, antes, a desconstrução crítica e analítica de "o Islão". O presente artigo propõe uma primeira incursão nesse sentido pelo discurso português.

1. No Outono de 1990, na sequência da queda do Muro de Berlim e já após a invasão do Kuwait pelo exército iraquiano de Saddam Hussein, com a Guerra do Golfo, ainda incerta, mas já provável, por pano de fundo, a revista Finisterra publicou um número de reflexão em torno da reconfiguração da Europa e da 'Nova (Des)Ordem Internacional'. Entre os autores que para ele contribuíram figura Alfredo Margarido, que centrou o seu artigo especificamente na questão do factor religioso das transformações em curso e no Islão em particular e que - redutiva e distorcidamente, ou, tendo em conta a recepção que viria a ter a fórmula huntingtoniana, talvez antes prescientemente e em sintonia com o Zeitgeist - descreveu o conflito iminente no Golfo como uma "guerra entre os muçulmanos e o Ocidente" (Margarido, 1991: 44). 
Partindo de uma narrativa da relação entre a religião, a modernidade e a política que faz assentar no processo de laicização (determinante da "capacidade renovadora das sociedades", 34 ) e no individualismo (sua condição, 35), o despoletar da modernidade prometaica ocidental, o autor passa então a uma análise do Islão e do mundo islâmico abordados por referência aos tópicos de maior actualidade na conjuntura: as questões do véu islâmico nas escolas francesas, da fatwa contra Salman Rushdie, da diabolização da América na retórica do Ayatollah Khomeni, e do integrismo e terrorismo. O que cada um desses tópicos revela, é, afinal, a própria essência e natureza do Islão: o obscurantismo retrógrado que o uso do véu não apenas simboliza mas faz fisicamente valer, salvaguardando a hiper-masculinidade da sociedade civil e reduzindo a mulher à condição de escrava sexual e cívica $(38,45)$; a violação dos direitos humanos e das normas jurídicas de soberania nacional e internacional ("o processo muçulmano [...] repele todo e qualquer direito, para o substituir pela irracionalidade da religião", 47); e, particularmente, a importância ("elemento absoluto, que não encontra paralelo entre nós”, 42), e vertiginosa politização do religioso, que remete o seu discurso político e social para a ordem do transcendente absoluto e incomensurável. Estas questões, por outras palavras (e elas são "questões", porque entram em contradição com a modernidade ocidental), são simultaneamente imputadas como da essência religiosa do Islão e reveladoras da sua natureza como não-Ocidente. "As sociedades islâmicas não produziram ainda nem Galileus nem Darwins” (45), diz Margarido em suma. Ou seja, a sua história é a história do não conseguido; a perspectiva, portanto, a da História única da modernidade-ocidentalidade.

Deixando de parte alguns destes e outros aspectos da discussão do Islão no artigo que importaria não deixar passar acriticamente - como, por exemplo, a tendência para a indiferenciação entre o islamismo ou integrismo e o Islão (e a questão aqui não é apenas a da identificação redutora entre islamismo político e Islão, digamos assim, teológico, mas a própria não problematização da relação discursiva entre islamismo e Islão, para já não falar da ilegitimidade de se falar de islamismo e até de Islão no singular); ou, e muito particularmente, a teimosa recusa em entender ou pensar Saddam e o seu discurso em termos que não os de muçulmano, Istão e Jihad (43) - quero referir tão-só uma outra questão que a leitura deste artigo levanta e que tomarei como ponto de partida para a minha abordagem.

"Em tempos", diz o autor, "a administração colonial portuguesa consagrou às questões religiosas uma atenção sistemática, graças a investigadores como Silva Cunha, Silva Rego, José Júlio Gonçalves e alguns mais”. Ocupando-se da “'invasão' dos protestantes e muçulmanos”, sendo que os 
primeiros eram ao menos cristãos, "os muçulmanos", conclui, "apareciam - sobretudo na Guiné e em Moçambique - como o inimigo absoluto” (40).

Para quem, muito possivelmente, estranhe esta insólita nostalgia de um Alfredo Margarido exilado político, anticolonialista e crítico marxista, por essa preocupação governamental, que ele próprio designa por colonial, a restrição a que obedece quando declara que "evidentemente, ninguém pode defender a lógica policial de alguns destes trabalhos" parece corrigir o impulso, não fora o remate que logo se segue: "Não se pode contudo negar a lógica ou inquietações". Tanto assim, que efectivamente, no caso específico do Islão que faz objecto do seu artigo, e que é o que aqui nos interessa, a recuperação que Margarido opera quer da "inquietação", quer da "lógica", daquele discurso é, de facto, brutalmente clara: "Ora creio", conclui ele, "que se menosprezou a parte importante dessa tarefa de investigação, na medida em que ela mostrava a que ponto a acção catequista do Islão envolvia um projecto mais profundo, que não seria apenas o da expulsão dos brancos, mas a sua liquidação física" (40). E, lembrando a proximidade geográfica das fronteiras portuguesas com o Islão do Magrebe, fecha com um alerta e denúncia da inconsciência com que os ministros portugueses dos Negócios Estrangeiros e das Forças Armadas ignoram ameaça tão imediata e concreta (47).

Várias razões explicam a escolha do artigo de Alfredo Margarido como ponto de partida para a abordagem que aqui proponho. A primeira reside no facto de o autor fazer incidir a sua discussão do ressurgimento islâmico - e da importância que este vai crescentemente assumindo na consciência e no debate público europeus - especificamente na natureza do religioso no Islão. E de, ao fazê-lo, se reivindicar do exemplo das instituições e do discurso colonial português sobre o Islão enquanto ameaça. O essencialismo de uma visão orientalista do Islão combina-se e reforça-se assim com a lógica e inquietação nacional, e hoje securitária, que se transpõe para um mesmo essencialismo na compreensão das comunidades muçulmanas e da figura do muçulmano como problemas. Na perspectivação do muçulmano como ameaça, apreendido pela óptica do étnico, do político, do social, ou do económico, o Islão é precisamente esvaziado do seu sentido religioso, mas, antes de mais, e acima de tudo, dos sentidos que tem para os próprios muçulmanos.

Não nego que o cunho político, laico e marxista da abordagem de Margarido constitui uma segunda razão que pesou na escolha deste texto. Isto porque, para o período em causa, o período colonial, a produção portuguesa sobre o Islão é inteiramente de sinal oposto, e a citação de um qualquer dos tantos exemplos à mão arriscar-se-ia precisamente a reforçar os lugares comuns do já assente e, de tão assente, quase caricatural. Ora, essa caracteriza- 
ção do Islão como inimigo absoluto que Margarido atribui ao discurso do regime, e que é afinal aquela que ele próprio acaba por assumir, não deve, na verdade, ser aceite tão facilmente. Essa caracterização da relação dicotómica e simplista com o Islão foi ela própria construída através de um certo branqueamento da narrativa histórica colonial, que vigorou, aliás, num período muito curto do Estado Novo. Mas, pela conjugação de interesses políticos e identitários na conjuntura imediata do pós-25 de Abril - quando, por um lado, o então Presidente da Comunidade Islâmica de Lisboa, que até Abril de 1974 fizera o jogo da apologia do lusotropicalismo pluri-racial e pluri-religioso português, passa a denunciar o anti-islamismo do fascismo sionista português e, por outro lado, o regime revolucionário se via confirmado nas suas credenciais revolucionárias pela adopção da causa terceiro-mundista do mundo árabe e a esquerda liberal afirmava a solidariedade com a causa palestiniana -, e desde esse momento - quando o regime democrático, uma vez estabelecido, vê na abertura para com o Islão a prova da superação de um nacional-catolicismo salazarista, as autarquias, do Alentejo e Algarve em particular, novamente prestigiadas, vão encontrar no passado árabe um motivo de diferenciação cultural e de investimento patrimonial e turístico e a sociedade portuguesa, espelhada nos currículos escolares e nas novas narrativas museológicas e historiográficas da nação, nele se revê multicultural e tolerante - a caracterização referida acabou precisamente, por razões inteiramente diversas, se não opostas, por ser reproduzida e reforçada. ${ }^{1}$

Uma última razão, tem a ver com a evocação específica que Margarido faz das contribuições de Silva Cunha, Silva Rego e José Júlio Gonçalves. A produção destes autores sobre o Islão, no quadro institucional do Centro de Estudos Políticos e Sociais da Junta de Investigações do Ultramar, em Lisboa, e suas Missões de Estudo em Angola e Moçambique, (cujos relatórios foram estudados na perspectiva da relação entre antropologia e colonialismo por Donato Gallo (1989) em livro que Margarido prefaciou e que, portanto, bem conhece), obrigam - duma forma que deveria ter dado que pensar a Margarido - a articular a já referida questão da relação entre discurso e objecto com a sua estruturação por um centro metropolitano, produtor de sínteses e de teorizações generalizadoras e abstractizantes, por um lado, e em relação com saberes locais e empíricos, em terrenos constituídos como periferias coloniais, por outro.

\footnotetext{
${ }^{1}$ Em "Novos (ante-)passados: a invenção do Gharb al-Andalus português", um estudo que espero publicar brevemente, procedo a uma análise mais desenvolvida deste processo.
} 
2. A abordagem crítica destas articulações, assim como a justificação da sua relevância actual, tem que assentar numa análise concreta e fundamentada do desenvolvimento do discurso português sobre o Islão e os muçulmanos, que aqui procurarei resumir por referência a algumas vertentes particularmente pertinentes. ${ }^{2}$

O factor estruturante da relação entre Portugal e o Islão ao longo de todo o terceiro período colonial foi o do contexto africano e o conceito de "Islão Negro". O que tal noção implicava de imediato era uma diferenciação do Istão em contexto africano por comparação com o suposto Islão-padrão, o Islão árabe, e, por arrastamento, a noção do seu abastardamento. Igualmente subjacente, como termo de comparação e legitimação, implícito ou explícito, era o contraste entre o Cristianismo, cuja doutrina, simbolizada pela Trindade, se apresentava complexa e exigente, mas que se mantinha uno, universal, intransigente e incorruptível na sua doutrina e práticas, e o Islão, cuja crença simples se reduziria a uma simplista unicidade de Deus, mas que, porque religião plástica, adaptável, sincrética e contemporizadora (aliás, porque por natureza sensual, mundana e de moral laxa), degeneraria em diversas e incoerentes variantes locais. Religião que, na conclusão de Silva Rego, "não resiste nem pode resistir a duas horas de pensamento sério" (Rego, 1939: 51-2).

Correspondentemente, a islamização resultava superficial, como a designação islamizados, em vez de muçulmanos, claramente conotava. Como todos os estudos, de missionários a administradores, nunca deixavam de observar, "o conhecimento da religião que professavam era escasso ou nenhum”. A expansão do Islão explicava-se perfeitamente pela ascensão social com que estava conotada para o Africano, e que era explorada pelos marabus, ou pela sedução de iniciação e pertença às estruturas das confrarias. Em reforço do preconceito cristão de que o Islão era uma religião falsa, fruto de um plágio, para mais mal executado, do cristianismo e judaísmo, vinha a noção de que a religião se expandia à custa da esperteza velhaca do muçulmano, com as suas técnicas caquécticas, resumidas na fórmula do "prestígio do balandrau", que José Júlio Gonçalves dissecou enciclopedicamente nos seus vários estudos. Nestes e noutros "estudos" afins, o Islão projectava-se topograficamente sobre as plantas étnicas das províncias, reduzindo o Islão a etnicidade, seita ou dimensão do social.

Se, por altura dos Relatórios das Missões de Estudo de Missionologia Africana, agora em 1960, Silva Rego já se fazia arauto de uma nova missionação face ao Islão, uma missionação de "esforço-compreensão" e

\footnotetext{
${ }^{2}$ Para uma análise mais desenvolvida, em que assenta a presente síntese, ver Vakil (2003a).
} 
não "esforço-refutação", para usar os seus próprios termos (1960a: 111, 1960b: 122), é porque afinal esta resultava a melhor estratégia visto que, convidado a expor a sua religião, o muçulmano seria ele próprio levado a enxergar as contradições e fragilidades da mesma e a compreender a inferioridade perante o cristianismo. Mas, embora neste importante texto, que se pretende de orientação para política futura, se atribua o sucesso do Islão à dignificação da pessoa humana, a identidade do muçulmano é ainda, essencialmente, feita assentar no meio social e étnico e dada como dependente deste; arrancado do meio, melhor se evangelizará. Afinal de contas, todo os seu catecismo se reduz a isto: "alguns dias bastam para um indígena se saber enrolar num lençol, aprender que Alá é o único profeta de Deus" (Rego, 1960a: 128, 1960b: 116). Além de que um terceiro elemento se define: o Islão, o verdadeiro, é o fanatismo da sujeição absoluta e inquestionável - "Recorde-se a propósito", diz Rego, "que um muçulmano que discute assuntos religiosos é já muçulmano meio abalado. O alcorão proíbe qualquer discussão" (1960a: 112, 1960b: 123). Ora, sob o impacto da ocidentalização, o Islão está minado pelo modernismo, a ortodoxia desaba e, assim, o muçulmano resvala para o nacionalismo que tende agressivamente para a hegemonia.

O segundo factor estruturante em que assenta o discurso português sobre o Islão é o culturalismo. Definido o Islão, na expressão de Teixeira da Mota, como civilização, cultura e bandeira (1954: I, 257), não apenas, mais uma vez, se esvazia a dimensão do religioso mas, com consequências óbvias, se reduz o Islão a barreira cultural, força deseuropeizante, e desaportuguesadora. Não apenas estranha ao corpo da nação, mas desestruturadora dele. Desde António Enes, Serpa Pimentel, e Jardim Vilhena, e os seus relatórios de governo, a Jorge Dias e os seus relatórios de campanha das Missões do CEPS, os "comerciantes monhés", a "praga asiática" e, sobretudo, o "indiano maometano", se apresentam, nas palavras deste último, como "grave ameaça à soberania portuguesa" devido ao obstáculo que criam à unidade cultural nacional (Dias, 1956: 1-16 e 21-23). E se, para uns, o aportuguesamento dos muçulmanos era a política óbvia, outros, como o padre, e pretenso islamólogo, Porfírio Gomes Moreira, nos seus "Apontamentos sobre o Islamismo" (1967) apresentados às mais altas autoridades militares de Moçambique, e o padre Albino da Silva Pereira (ou Lobiano do Rego, de seu nome literário, celebrizado pelo aval de um prefácio de Gilberto Freyre ao seu livro Pátria Morena), em livros, panfletos, artigos e em carta enviada ao Governador Geral de Moçambique, continuaram, já pós-Vaticano II, a avisar incansavelmente, que "não faz sentido um muçulmano português", “o muçulmano não é, nem pode ser português” (Rego, 1965: 290, 413-414, 
1959, 1969); e, especialmente, que a comunidade islâmica de Lisboa, com ambições expansionistas, "não pode ser senão, como primeira intenção, o enraizamento de um cancro no corpo político da nação" (Rego, 19703, 1966).

O terceiro factor estruturante é o geoestratégico, cuja configuração se inscreve na elaboração da versão portuguesa do discurso da Guerra Fria e acompanha este. A sua origem remonta à redescoberta, por Eduardo Dias (1946), de que "ainda existem Mouros em terras de Portugal". No contexto do imediato pós-II Guerra, em que também a Rússia se identifica como nova ameaça asiática, aquela redescoberta do maurrasiano "pesadelo islâmico", desdobra-se agora simultaneamente num sistema político-religioso irmanado e conexo com o bolchevismo, e ameaça directa à soberania nacional por quintas colunas nas colónias africanas. É ainda com referência ao "perigo vermelho" "mancomunado" com o "perigo turco" que Sousa Franklin (1956) lança novo alerta à nação em comunicação ao IV Congresso da União Nacional. Mas a ameaça à soberania nacional que ele denuncia centra-se já, mais insistentemente, na impossibilidade de assimilação dos muçulmanos culturalmente árabes na cultura nacional portuguesa e, portanto, no corpo da nação. É, porém, com Adriano Moreira (1955, 1956a, 1956b, 1963) e a identificação definitiva da frente anti-colonialista "afro-asiática" saída de Bandung, que se realiza a formulação paradigmática do discurso português sobre o Islão em termos que articulam uma visão de política colonial com a linguagem e visão da geoestratégia e das relações internacionais; caberia a José Júlio Gonçalves (1958a, 1958b, 1958c, 1960, 1961), por sua vez, fazer assentar essa formulação na "realidade concreta" do Istão no espaço português. É dentro deste paradigma e discurso que o muçulmano se consubstancia na "ameaça absoluta" a que Alfredo Margarido se refere.

Mas, precisamente, o que interessa notar aqui, é o carácter fantasmático deste Islão. O Centro de Estudos Políticos e Sociais existe como uma espécie de cúpula (metropolitana) do sistema mas estruturada numa articulação desarticulada com as instituições e realidades no terreno (das periferias coloniais). O ponto a reter, em síntese de síntese, é que nenhum dos programas especificamente direccionados para o "problema" islâmico se veio a informar por este paradigma.

Nem em Timor nem na Índia Portuguesa a presença muçulmana e do Islão levou à produção de um conhecimento específico e sistemático sobre estes elementos da população, ou sobre a sua cultura e religião, cujo impacto, localmente ou em Portugal, se fizesse sentir no relativo à formulação de

\footnotetext{
3 Artigo de jornal não identificado com que o autor fez acompanhar as suas cartas ao GG de Moçambique e Governo do Distrito de Manique e Sofala, IANTT: SCCIM Cx. 384, fls. 178-179 e Cx. 221 fls. 381-382.
} 
políticas de governação, administração ou policiamento civil ou militar, à ideologia e retórica do discurso colonial, ou à investigação sócio-antropológica (como imediatamente ressalta da própria produção bibliográfica do CEPS sobre a Índia e Timor, aliás escassíssima ${ }^{4}$ ). Se, no caso de Timor, o facto da sua implicação no cruzamento das disputas políticas internas e externas da Indonésia, da Malásia, e do movimento afro-asiático torna o Islão factor relevante, essa importância não decorre da presença islâmica em si, e não se reflectiu directamente sobre os muçulmanos da província, que pouca preocupação suscitaram. ${ }^{5}$ Em Goa, Damão e Diu, são já outros factores a pesar, entre os quais o bloqueamento ideológico não será dos menos relevantes. ${ }^{6}$ É na Guiné e em Moçambique que essa presença se traduz num problema que a constitui como objecto de discurso. Na perspectiva restrita da questão das articulações que levantei, são diferentes as conclusões a que cada um destes dois casos leva.

No caso da Guiné, dispondo, com o Centro de Estudos da Guiné Portuguesa, de uma instituição única no espaço colonial português vocacionada para a produção de um saber-poder ao serviço do Governo colonial, o ponto a reter é que quando no período da guerra colonial se veio a articular uma política islâmica oficial, e, mais sistematicamente, uma política de conquista das populações, não se reconhece qualquer aproveitamento deste saber e suas estruturas por parte do novo projecto gerado no meio militar. Aliás, o que transparece marcadamente da leitura dos textos de Spínola que lhe dão corpo e voz é que o discurso islâmico é formulado em termos de generalidades sobre o Islão que não assentam em qualquer conhecimento profundo ou detalhado, quer dos textos (e do próprio Corão que serve de base às citações de que o discurso superficialmente se reveste), quer das formas sociologicamente assumidas pelo Islão nas comunidades muçulmanas, ou

\footnotetext{
${ }^{4}$ Vejam-se, como exemplo, as contribuições de Neto (1968), Simões (1968) e Carvalho (1968).

${ }_{5}$ Ver, por exemplo, os relatórios confidenciais Análise do Quadro de Estruturas da Província de Timor elaborados pelo Comando Territorial Independente de Timor. Quartel General, 3. ${ }^{a}$ Repartição, 1965 e Actualização, 2. ${ }^{a}$ Repartição, 1969, in AHM Div. 2 Sec. 9, Cx. 5 n. ${ }^{\circ}$ 1. Os estudos há muito esperados de Moisés Silva Fernandes sobre "o movimento protonacionalista islâmico-malaio em Timor" e sobre a documentação da PIDE/DGS relativa a Timor permitirão avaliar melhor esta questão. Também as notas sobre Timor elaboradas por Suleiman Valy Mamede no Gabinete de Negócios Políticos do Ministério do Ultramar existentes no Arquivo Histórico Ultramarino para as quais Moisés Fernandes e Cláudia Castelo me alertaram, mas que ainda não pude consultar, poderão levar a alguma revisão sobre a questão.

${ }^{6}$ Se os muçulmanos figuram como preocupação pontual em notas remetidas para Lisboa pelas autoridades militares (agradeço a Rosa Maria Perez a indicação sobre as notas no AHM), não chegam porém a ser objecto de preocupação específica ou estudo sistemático; com a excepção de notas muito elementares de carácter etnográfico e de alguns estudos antropo-biológicos, sobre um ou outro aspecto de culto religioso, ou sobre direito islâmico, nada de significativo consta na bibliografia portuguesa do período.
} 
das suas práticas religiosas ou culturais no terreno. Quer pelo já citado alerta de Sousa Franklin para a ameaça islâmica, por um lado, quer pelo prestigiar do valor militar dos muçulmanos como auxiliares dos portugueses (desde a heroização do soldado indígena nas exposições coloniais nacionais e internacionais dos anos 30 às condecorações dos anos 70), quer através das referências aos muçulmanos da província pelos seus governadores, desde Sarmento Rodrigues a António Spínola, foi sempre principalmente com base no caso da Guiné que o Islão, fantasmática ou ponderadamente, mais se fez sentir em Portugal. Mas se a produção etnográfica e historiográfica, por um lado, e o discurso ideológico, por outro, influíram directamente nos estudos e visão do CEPS e nos meios políticos e ultramarinistas em Portugal - incluindo Silva Cunha, o Gabinete de Negócios Políticos e o Ministério do Ultramar em geral, com reflexo por exemplo nas políticas de abertura de mesquitas e de peregrinação a Meca - nem aquela nem este tiveram qualquer eco ou relevância no momento de intervenção junto das comunidades islâmicas, nem o factor islâmico na colónia alguma vez transcendeu essa importância local.

É aqui que o caso moçambicano assume interesse particular. Três pontos fazem destacar esse interesse. Primeiro, ao contrário da Guiné, o desenvolvimento de um projecto visando o comprometimento do Islão com o poder português passou por um esforço planeado e sistematicamente realizado de conhecimento em pormenor do Islão nas suas realidades concretas. Segundo, o comprometimento visado passava intrinsecamente pela criação de um discurso islâmico português e em português, e, no limite, de um Islão português. Terceiro, longe de um projecto meramente reactivo e circunstancial, ditado pela conjuntura doméstica, ambicionou-se, com base numa concepção geoestratégica das linhas de força ideológicas das orientações e potências islâmicas globais, instrumentalizar o Islão local como ponto de articulação de uma política externa actuante no tabuleiro do próprio campo do Islão. No cruzamento destes três pontos, está, como arquitecto de cada um deles, Fernando Amaro Monteiro. ${ }^{7}$ No circunstancialismo da centralidade de um individuo - e deste indivíduo -, por um lado, e da personalização consequente destes projectos, por outro, residem por igual os pontos fortes e a debilidade do todo.

No que às formas de conceptualização e construção do Islão diz respeito, importa reter o seguinte. Amaro Monteiro começou a explorar e aprofundar o seu conhecimento do Islão em conversas informais, de carácter pessoal,

\footnotetext{
7 Toda a discussão que se segue tem por base as entrevistas com Fernando Amaro Monteiro gravadas entre 18 de Fevereiro e 2 de Abril 2004 que constam do livro em co-autoria que brevemente irá ser publicado.
} 
e, o que é particularmente significativo, em relação firmada entre crente (católico) e crente (muçulmano) com Amad Dulá Ismael, influente figura do Islão local (Monteiro, 1975), frequentando o seu meio familiar. Só depois os seus conhecimentos foram complementados com leituras. Integrado nos Serviços de Centralização e Coordenação de Informações de Moçambique, Amaro Monteiro faz sentir a importância estratégica do Islão na geografia humana e política da Península e, coligindo e sistematizando o que até então dispersamente se elaborara entre arquivos históricos e investigações e informações pessoais ou de carácter militar, policial e administrativo, faz, em 1966, lançar um inquérito à escala do território que visa não apenas um levantamento completo das comunidades, hierarquias, e linhas de articulação, mas uma primeira sondagem aos próprios sentidos da visão religiosa dos muçulmanos sobre pontos susceptíveis de aproveitamento político-religioso e cultural. Este inquérito foi, por sua vez, suplementado por missões de estudo e aprofundamento baseadas em conversas pessoais com as autoridades apuradas como cúpulas das hierarquias, por um lado, e, após um aprofundamento do conhecimento do Islão através de um curso de especialização islamóloga no Instituto de História dos Países do Ultramar da Universidade de Aix-en-Provence, conduziu à implementação de uma política concertada por parte do Governo Geral (Monteiro, 1993).

Analisando o arquivo documental do projecto ${ }^{8}$, e comparando esta documentação com os relatórios da administração civil, da PIDE/DGS, e os relatórios militares, ou os projectos católicos de abertura da Igreja para com os muçulmanos ou de resistência ao pluralismo religioso e ecuménico, sobressaem, precisamente, dois pontos. Primeiro, na primeira linha de contacto com os muçulmanos, impera um empirismo de observação fundada no preconceito de que o religioso encobre uma fenomenologia de carácter social (étnica e tribal), quando não explicitamente política e subversiva; e em que a ignorância se traduz sempre pela suspeição. Se entre os administradores de posto (mesmo os com responsabilidade sobre populações maioritariamente muçulmanas), impera a ignorância total sobre os factos mais elementares do Islão, entre os batedores e informantes, essa ignorância, exacerbada ainda pela óptica policial, deforma desde a primeira instância o próprio registo descritivo que se transmite pela cadeia de circulação informativa. Segundo, e pelo lado oposto, as abordagens textuais, quer dos próprios livros da tradição islâmica, quer dos de divulgação sobre o Islão correntes na altura, levavam a uma compreensão árabo-cêntrica do Islão e exclusivamente centrada na alta tradição normativa, de que resultava uma

\footnotetext{
${ }^{8}$ Fundo integrado no IANTT: SCCIM, Caixas 36, 47, 71, 126, 133, 167, 209, 221, 273, 277, 307 , $308,380,384,395,497$.
} 
não menor deformação, quando não mesmo incapacidade de apreensão das realidades concretas das comunidades muçulmanas locais. O projecto de Amaro Monteiro, visando superar estas limitações pela análise textualmente informada da realidade local, mas trazendo àquela um conhecimento que já partira de alguma familiaridade concreta, constituiu um passo na ultrapassagem deste problema. Os limites decorrentes de um projecto quase só individual, que no local dependia daquele mesmo pessoal administrativo sem preparação adequada, e concebido a contra-relógio com um fim político imediato, acabaram, porém, por circunscrever redutoramente o compasso do que foi abrangido neste primeiro olhar etnográfico sobre o Islão. Mais significativo ainda, porém, é o facto de que a relação entre o textual e o etnográfico que tentativamente transparece na sua prática, foi circunstancial; não só não chegou a emergir como questão metodológica, não chegou sequer a traduzir-se em dialéctica prática. Assim, mesmo neste primeiro e potencialmente mais interessante momento de produção, ainda que apenas incidentalmente etnográfica, sobre o Islão, é a lógica do Islão textual (como o próprio guião do inquérito desde logo demonstra ${ }^{9}$ ) que é determinante.

Onde essa lógica se faz talvez sentir mais particularmente é no projecto normativo da criação de um Islão português. O projecto era todo ele, para lembrar o óbvio, um projecto político-ideológico de reforço da autoridade e do poder colonial português. A lógica é culturalmente assimilacionista. A estratégia está fundada numa leitura ideológica do Islão que, tendo por critério o interesse nacional, territorialmente concebido, visa autonomizar os muçulmanos da província, nacionalizando-os, separando os "bons muçulmanos" dos "maus muçulmanos". É este desígnio que preside aos esforços de legitimar o princípio da tradução portuguesa dos textos da tradição islâmica e dos sermões nas mesquitas. É a mesma lógica ainda, viciando o já de si problemático ponto de partida de uma concepção textual normativa do que é o Islão, que informa um intervencionismo estatal que promove e institui a legitimidade e representatividade hierárquica religiosa numa religião sem Igreja, e procura "conduzir" o desenvolvimento dum Islão português "aceitável".

Quase poderíamos estar a falar do momento actual.

3. Pensar o Islão implica, antes de mais, problematizar a questão do que é o Islão. Estão aqui em jogo dois aspectos. Primeiro, pensar $o$ Islão através da questão da relação entre - para enfatizar o aparentemente paradoxal -,

\footnotetext{
${ }^{9}$ O guião do questionário está publicado em Monteiro (1993: Anexo 3); para as importantes notas de recomendação aos administradores responsáveis pela sua aplicação, ver IANTT: SCCIM Cx. 71, fls. 131-122.
} 
os muçulmanos e o Istão, entre a tradição textual, normativa, universal, e o Islão vivido, prático, contextual, local. Segundo, e tendo em conta a história das relações colonial e contemporânea das sociedades europeias, e da portuguesa, com o Islão e os muçulmanos, pensar o Islão implica antes de mais, a desconstrução de uma estruturação do Islão sempre especificamente como "problema".

$\mathrm{Na}$ sociedade portuguesa contemporânea, pós-colonial, o encontro com o Islão ${ }^{10}$, a sua apreensão e compreensão, a sua construção como objecto de interesse e discurso - primeiro diplomático e estratégico, depois-mediático, depois ainda, académico e cultural e, por último, securitário e policial -, exprime diferentes variações do Islão como problema. Mais especificamente, no contexto interno, o Islão emerge, com a descolonização e os "retornados" primeiro, e através da imigração económica depois, indistinguível das comunidades étnicas que o professam, e especificamente como fenómeno étnico. Gradualmente, e através das próprias vicissitudes da transformação da sociedade, cultura e política portuguesas e internacionais, esta dimensão vai-se traduzindo na questão da "integração": no problema da educação multicultural, no problema da dificuldade de assimilação das políticas comunitárias e identitárias, crescentemente vistas como desafio e problema. Depois, e pela força das circunstâncias externas, em que o Islão se vai impondo como problema simultaneamente sociológico, político, identitário, e de segurança, são questões externas, pensadas sem conhecimento concreto das circunstâncias das comunidades locais, que se vão transpondo e formulando em interrogações sobre os muçulmanos em Portugal. Na presente conjuntura, o transnacionalismo imigratório em que convergem as preocupações políticas populistas da imigração e da segurança cristaliza uma nova configuração do Islão como problema cultural.

Como porém, nem houve nem há em Portugal instituições, especialistas, ou tradição islamóloga em qualquer dimensão de estudos islâmicos (que não é o mesmo que arabismo ou história do Islão ou da civilização islâmica), donde, portanto, nem também uma opinião pública, ou fazedores de opinião pública, com conhecimento prático sobre a matéria, resulta que as respostas às solicitações impostas pela procura de soluções para cada uma destas formulações do Islão como problema não são nunca informadas por um conhecimento fundamentado do Islão religião, independentemente da relevância do mesmo. O problema começa pelo mais básico da questão de pensar o Islão, que é a inexistência de consenso sobre a terminologia mais elementar, logo desde a do uso do termo Islão ou Islamismo, para designar

${ }^{10}$ Para uma breve síntese da implantação e formação das comunidades muçulmanas no Portugal contemporâneo, ver Vakil (no prelo). 
a religião, e (pressupondo generosamente que maometanos já caiu definitivamente em desuso), de islâmicos, islamitas, islamistas, ou muçulmanos, para designar os que dela se reclamam. Começando pelo plano terminológico, esta indeterminação, particularmente na indiferenciação entre Islão e Islamismo, reflecte-se na falta de rigor analítico em torno da relação entre o religioso e o político, entre a religião e os movimentos sociais, as mobilizações políticas e as ideologias.

Se a ausência de consenso terminológico (e, aliás, de normas de transcrição e de vocabulário islâmico português), reflecte a inexistência de uma tradição orientalista de estudos islâmicos, a produção académica recente sobre o Islão e as comunidades islâmicas acumula novos problemas. A institucionalização académica dos Estudos Religiosos não ultrapassou ainda, em geral, os paradigmas dos estudos teológicos católicos da tradição portuguesa; como esta é ainda principalmente texto-cêntrica e histórica na discussão do Islão e, quando dá espaço a vozes muçulmanas, tende, em parte por razões que reflectem as debilidades sociológicas da própria comunidade muçulmana, e em parte em consequência duma falsa noção de legitimidade da auto-representação, a privilegiar a perspectiva "teológica" e tradicional em detrimento das perspectivas académicas, críticas e de diversidade. Nos estudos sobre as comunidades muçulmanas em Portugal, em que o historiográfico prima pela ausência, sobressai uma produção sociológica e antropológica caracterizada pelo estudo de comunidades etnicamente segmentadas (os muçulmanos guineenses, os indianos, os marroquinos, os bangladeshianos; quando não os bangladeshianos do Martim Moniz, os marroquinos de A-Ver-o-Mar, etc.); uma tensão não resolvida (e, aliás, só por excepção reflexivamente assumida) entre uma visão descritiva e émica do Islão (acriticamente reproduzida) com base no método das histórias de vida ou de entrevistas, e as visões históricas, textuais, e essencialistas do Islão estabelecidas pela citação acrítica dos textos "sagrados" dos muçulmanos; a quase completa ausência de recurso a arquivo documental que vá além de artigos de imprensa, sempre citados como único registo histórico; e a ausência de estudos comparativos com outras comunidades europeias ou com as comunidades de origem. ${ }^{11}$ Mas há duas outras questões mais fundamentais. Por um lado, e em parte por razões que se prendem com a obtenção de financiamento dos projectos de investigação, os estudos tendem ou a focar, ou a construir discursivamente, o seu objecto como problema e a privilegiar a utilidade prática do estudo para a elaboração de políticas

${ }^{11}$ Sobre a história e historiografia das comunidades muçulmanas em Portugal, ver Vakil, 2003a; sobre os estudos académicos, AbdoolKarim Vakil, "A arte de fazer ser muçulmano português: panorama crítico de um campo de estudos em formação”, a ser publicado. 
interventivas, evidentes sobretudo nos estudos sobre educação multicultural, por exemplo, sobre a integração de imigrantes ou sobre a "mulher muçulmana". Por outro lado, há uma forte (embora geralmente apenas implícita) vertente normativa que celebra e de certa forma procura encorajar e moldar a emergência de um Islão Europeu, as manifestações de Reforma, a integração, e a moderação.

Em termos da esfera pública, a presente configuração do "problema islâmico" em Portugal é de ordem cultural e da politização dessa questão em torno da questão da imigração-assimilação/integração cultural por um lado, e da questão da violência, do terrorismo e da segurança, por outro. Se já o próprio Samuel Huntington havia transposto a questão do choque das civilizações (1993) do plano internacional para o campo de batalha do multiculturalismo no interior da nação (1996), Roger Scruton resume o passo lógico seguinte. Extremados os "dois campos" (para nos valermos da expressão de Maria Filomena Mónica num texto que irei analisar) e reformulado o conflito em torno da ocidentalidade e da rejeição dos seus valores, é com as comunidades muçulmanas na Europa - as quintas colunas dos filhos dos imigrantes que, cheios de ódio, se lançam à destruição das sociedades que tão generosamente os acolheram, anulando, pela sujeição a Deus e à sua Lei, os laços de cidadania da comunidade de pertença, tão enfraquecidos, já, pela lógica apartheidista do multiculturalismo -, que a questão mais aguda, urgente, e ameaçadoramente se põe: questão de lealdade e pertença, para Scruton (2002); “vexata questio da razão tolerante face aos seus adversários”, na formulação de Diogo Pires Aurélio (1997: 74).

A obra Os sentimentos de uma ocidental, colectânea de textos de Maria Filomena Mónica, reflecte bem a construção da problemática em causa. A razão de ser do título, explicada pela autora no prefácio, foi o "vigor inesperado" com que, perante o 11 de Setembro, lhe surgiu "o sentimento de pertencer à cultura ocidental" (2002: 9). O sentido dessa pertença adquire algum contorno na afirmação da autora de que, rapidamente percebeu "de que lado estava". O que resta saber, é quem ou o quê se entende como o outro lado. O título do livro remete para o artigo "O sentimento de uma ocidental", publicado no jornal Público de 26 de Outubro de 2001. Deixando de parte a evocação do poema de Cesário Verde que, com a sua visão nostálgica e pessimista das sombras negras que pesam sobre as massas da cidade ocidental, talvez seja bem mais ambivalente do que a autora pretendeu, o tema do artigo é a defesa de Berlusconi contra o que chama a praga do politicamente correcto, em nome da legitimidade de se afirmar inequivocamente a superioridade da civilização ocidental. A pluralização de que o título se reveste, ao passar de "O sentimento" no artigo para "Os 
sentimentos" no livro, cria a unidade orgânica da colecção que faz de cada um dos artigos uma expressão dessa ocidentalidade, através dos quais o "outro campo" (no singular), como se lhe refere no prefácio, vai ganhando sentido e expressão: ele é, como pelo assumir da posição de Berlusconi já ficara implícito, não Bin Laden, ou o terrorismo 'islâmico', mas a não-civilização do Islão. Assim, do orientalismo humorístico e acrítico de veia queirosiana, mas despido do elemento de crítica imperialista de Eça (cf. Vakil, 2000), em "Poderá a história repetir-se?” (167-170), a autora passa do bando religioso dos talibãs para a generalização de um extremismo político islâmico dado como resultado, não de uma relação já histórica, e especificamente estruturada em termos coloniais, com o Ocidente, mas tão-só das "dificuldades que as sociedades atrasadas enfrentam quando entram em contacto [maravilhoso e anódino eufemismo, A.V.] com o mundo industrializado" (169) (tese, note-se de passagem, que a autora corrobora por apelo à autoridade de V. S. Naipaul, citado como "homem inteligente e conhecedor dos países islâmicos" - o mesmo Naipaul que, no livro citado pela autora, expressamente declara que, antes daquela, sua primeira incursão pelo mundo islâmico, mais não conhecia do Islão, nem tivera curiosidade de conhecer, do que aquilo que "de fora" se lhe dera a ver na infância em Trinidade ${ }^{12}$ ).

De uma referência sugestivamente contextualizadora ao "Islão" (com aspas) como amálgama de costumes, tradições, e preconceitos no artigo "Como se pode ser afegã?" (179-182), logo, porém, se resvala para a inferioridade da mulher citada como preconceito da "maioria dos muçulmanos". Mas o aspecto que me interessa aqui mais particularmente, é a questão levantada no texto "Os imigrantes" (275-278). Neste artigo, a autora conjura o caso de Bradford, "cidade inglesa onde existe uma importante comunidade paquistanesa”, como paradigma da reacção da segunda geração imigrante (jovens nascidos na Inglaterra, cidadãos ingleses, mas na óptica da autora "imigrantes" ainda, de segunda geração, supõe-se, dado o facto de aos seus progenitores se chamar "os imigrantes de primeira geração"). Estes jovens, diz a autora, "tendem a desenvolver ideologias agressivas, a isolar-se da cultura comum" (contraditória escolha de termo que mal esconde a intenção ideológica) "e a reclamar uma identidade perdida" (qual?). E é aqui que chegamos ao ponto chave: "Por ora, em Portugal', afirma a autora, "o problema não é visível. Mas não tardará a emergir. Por isso vale a pena reflectir, desde já, sobre ele. Até que ponto pode um país tolerar aspectos culturais que lhe são odiosos" (277), como a prática de casamentos força-

\footnotetext{
${ }_{12}$ Naipaul (1982: 15-16); confrontar o comentário de Mónica com o de Edward Said sobre o mesmo livro (2000: 113-117).
} 
dos, e da excisão feminina. O multiculturalismo, palavra que, segundo a autora "não envolve apenas o suchi $[$...] mas o apedrejamento de mulheres adúlteras" [!], teve um tempo próprio e função correctiva que remetia para a limitação da arrogância do homem branco; ultrapassado já "o tempo do complexo de colonizador" e "expiadas as culpas" há agora que repudiá-lo. E, repetindo que "as sociedades ocidentais têm de possuir a vontade, e a coragem, de impor a estes indivíduos as leis e a língua do país", conclui: "os 'bárbaros' não estão às nossas portas. Estão entre nós” (278). A transposição do problema de Bradford para Portugal, implica necessariamente que as causas do problema não são contextuais (de um contexto, aliás, que não temos nenhuma razão para supor que a autora se deu ao trabalho de conhecer, nem in loco, nem por etnografia de poltrona - e em que não seria irrelevante ter em conta a história da imigração laboral ex-colonial dos paquistaneses que se estabeleceram em Bradford, a marginalização sócio-económica dos jovens, a discriminação racial, o papel da extrema-direita, e a islamofobia), ${ }^{13}$ mas sim da mentalidade ou cultura dos muçulmanos e da essência do Islão. Lógica análoga informa os textos de Diogo Pires Aurélio sobre a tolerância (1996: 179-230, 224-225, 1997: 73-74, 119, 1998: 306; 203, 2004a, 2004b) que, de uma discussão histórica e filosófica do conceito, sistematicamente resvalam para um enquadramento paradigmático dos problemas do multiculturalismo, e do intolerável em torno do Islão e das comunidades muçulmanas no Ocidente.

O maniqueísmo impera. Nos termos da dicotomia, acasalam-se as assimetrias: do Ocidente e do Islão; da modernidade e do arcaísmo; da razão e do fanatismo e irracionalidade; do secularismo e da teocracia; da democracia e do islamismo; da liberdade e do terrorismo. Se em cada pólo os termos se fundem nas noções extremadas de civilização ocidental e islâmica, a lógica que constitui a sua oposição como impasse é ela própria o resultado de um impasse. De um impasse que decorre de um discurso em que o outro é coisificado e sistematicamente interpretado a partir de um esquema pré-estabelecido, e infundado, ou seja, da má fé (Gil e Tunhas, 2003: 82, 97). O livro Impasses, de Fernando Gil e Paulo Tunhas, é o melhor exemplo disto. A polémica com que, por boas razões, o livro foi recebido em Portugal (o ajuste de contas com a esquerda, a instrumentalização retórica da acusação de anti-americanismo, a discussão, e o tom da discussão, da legitimidade, razoabilidade e justificação da guerra no Iraque, e a pobreza da

\footnotetext{
13 Ver a excelente discussão destas questões, para o caso dos muçulmanos de Birmingham, em Hewer (2003) e o resumo de Carvel (2004) dos problemas sócio-económicos que afectam as comunidades muçulmanas do Reino Unido revelados pela análise do Censo nacional de 2001.
} 
análise, particularmente nas incursões pelo psicanalismo barato, do terrorismo, da al-Qaeda, de Osama bin Laden, dos palestinianos, ou dos terroristas-suicidas), é aqui pertinente apenas pela omissão nela da questão que, na perspectiva deste artigo, se afigura principal: o interesse e importância do livro residem no facto de pôr directa e explicitamente a questão que na presente conjuntura estrutura a percepção do Islão e dos muçulmanos, a questão da relação entre o terrorismo que se proclama do Islão e o Corão. $\mathrm{O}$ aspecto que faz cair por terra a análise é precisamente a deficiência da abordagem do Corão e da sua relação com o Islão. Essa deficiência radica no método adoptado.

Um exemplo do método anedótico e impressionista é o caso da empresária francesa vivendo em Rabat em precária e incómoda situação de clandestina concubinagem com o namorado, porque casar "a obrigaria a converter-se e a aceitar a lei corânica. Ou seja, a aceitar ser repudiada, a dever tolerar a eventual poligamia do marido, etc." (Gil e Tunhas, 2003: 191-192). A descrição do caso, a sua inclusão no capítulo e o seu lugar como ponto de passagem específica para a citação do Corão e da apresentação do estatuto da mulher no Islão são significativos. Poderíamos, antes de mais, interrogarmo-nos sobre se o risco a que esta francesa se expunha quanto ao repúdio e, especialmente, à eventual poligamia do marido se ficaria a dever à permissividade da lei islâmica ou ao marido, em quem ela obviamente não confia o suficiente. A importância da questão, porém, vai muito além do plano anedótico. O facto é que, como Norman Daniel demonstrou no seu estudo já clássico da polémica anti-islâmica no ocidente medieval (1960: 160-161), uma das constantes desse discurso, com incidência precisamente sobre os temas do repúdio e da poligamia, é a acentuação do que os textos permitem em detrimento das práticas efectivamente vividas, e o salto da presunção da suposta permissividade para a conclusão de que ela será sempre realizada. Mas o que a citação deste caso pelos autores mais profundamente ilustra é o problema da falta de rigor na análise do objecto em discussão: as constantes derrapagens no texto, e consequente esbatimento, entre o enfoque proposto sobre o terrorismo e uma caracterização (mas não uma discussão ou análise crítica) mais generalizada do Islão. Assim, para o caso citado, a questão que importa levantar é a do sentido da islamicidade que lhe é conferido pelos autores. Afinal, na Tunísia, a poligamia e o repúdio estão ilegalizados pelo Código de Estatuto Pessoal desde 1961. Mesmo em Marrocos, a igualdade de estatuto legal do homem e da mulher está, desde Fevereiro de 2004, legislativamente assegurada (e se, em livro publicado em 2003, os autores não podiam, obviamente, referir o facto, já não se compreende a ausência de qualquer referência ao facto de o Rei 
Muhammad VI ter já desde 2001 estabelecido a comissão encarregada da revisão do código de família e de esta ser composta também por mulheres). Dado o facto de a igualdade de estatuto conferida, tida por verdadeiramente revolucionária, se reclamar especificamente em conformidade com o espírito e os princípios do Islão e como tal ter sido aceite pelos próprios sectores islamistas do país (Sardar, 2004b: 25-26), qual a natureza da incompatibilidade entre o Islão e a igualdade de direitos da mulher imputado pelos autores à lei islâmica? Por outras palavras, o que importa sublinhar é a historicidade do caso.

Se a questão não é intrínseca ao Islão, ou ao texto corânico, qual o valor desta descrição de caso neste capítulo do livro e como parte da sua argumentação? A nota de pé de página a este propósito é igualmente significativa. Retomando a questão do "repúdio", termo ["de sabor mais antigo e oriental" e como tal mais adequado à descrição do caso islâmico do que "divórcio", que parece "expressamente ocidental”, como já Silva Rego defendera (1961: 408)] com que os autores designam a prática de talak (pronunciamento unilateral de divórcio pelo marido), o caso islâmico é aí comparado negativamente aos casos cristão e judaico. Mas, conquanto em relação a este último se diga que o texto sagrado permite o repúdio, logo se especifica que "mas está sujeito a grandes restrições e existem contrapartidas femininas no repúdio". Não se entende porque é que, no caso do Islão, os autores se ficam pela suposta injunção do texto, sem atender nem às restrições semelhantemente erguidas na própria tradição jurídica, nem à comprovação histórica e etnográfica dessas restrições. Como, aliás, não se entende que se passe em silêncio a discussão da tradição islâmica de khul' (recurso pela mulher ao divórcio unilateral), cuja prática remonta ao tempo do Profeta, e cuja discussão, periodicamente renovada ao longo dos tempos, desponta de novo como recurso emancipatório nos debates contemporâneos, tendo, inclusive, o seu reconhecimento jurídico sido já consagrado no Egipto pela lei n. ${ }^{\circ} 1$ de 2001 (Fawzy, 2004).

Num capítulo que tem por objecto pensar a relação entre "as injunções" e "o gesto", esta parece ser uma lacuna fundamental. E é, de facto, uma lacuna que caracteriza toda a discussão do Corão como texto, inteiramente divorciado dos sentidos e conceitos de texto que o Corão tem para os muçulmanos, ou das suas formas de leitura e dos usos a que os muçulmanos e, particularmente, as muçulmanas o submetem. ${ }^{14} \mathrm{O}$ passo fundamental na

\footnotetext{
${ }^{14} \mathrm{O}$ reconhecimento dos papéis activos e da capacidade de negociação das mulheres muçulmanas perante uma sociedade, instituições e discursos teológicos e jurídicos patriarcais, pela recuperação de elementos potencialmente emancipatórios, igualitários, ou redistributivos (o que alguns diriam mesmo ser o verdadeiro espírito e intuito original da mensagem do Islão) do Corão e do direito
} 
construção do impasse é dado, porém, com a passagem da descrição do caso citado para a questão do estatuto da mulher muçulmana, que se resume e esgota na transcrição do versículo 34 da Surata IV do Corão (Gil e Tunhas, 2003: 192). A questão não é apenas o simplismo da pretensão implícita de que o texto citado fala por si. A questão é que o que essa forma de "argumentação" revela é a completa falta de atenção ao modo islâmico de ler o texto, ao facto de a própria tradição islâmica consagrar a noção de que o texto do Corão por si só não é necessariamente uma evidência capaz de resolver disputas de interpretação e ao princípio de que existem metodologias próprias de interpretação do Corão e de que há, pelo menos até certo ponto, um grau de pluralismo interpretativo irredutível. Parte do reconhecimento destes dois aspectos passaria pela obrigação de tomar em conta como este versículo tem sido historicamente objecto de interpretação e intensa disputa e de ponderar os usos a que ele se tem prestado na leitura e tradição jurídica. Aliás, a leitura que proclama a evidência da literalidade do texto corânico, sem necessidade de mediação, e que rejeita o confronto com o corpus jurídico consagrado pela tradição é, precisamente, a leitura dita "fundamentalista", subscrita por Osama bin Laden (Abou el-Fadl, 2003: 74-75), que os autores aqui aplicam e que, fazendo passar por islâmica, constroem em impasse. O mais irónico, a mais gritante má fé (ou, possivelmente, mera ignorância), é que, ao considerar a questão do estatuto da mulher, e ao citar um passo do Corão supostamente ilustrativo da condição subjugada da mulher muçulmana, os autores reforcem essa mesma lógica de subordinação passando em silêncio - nem citando nem referindo sequer a existência das leituras feministas islâmicas do Corão, e desse versículo em particular. ${ }^{15}$ Aliás, como voltarei a referir, toda a pluralidade e diversidade de leituras islâmicas emancipatórias, progressistas, feministas, críticas, cépticas do Corão estão omissas no livro, o que, obviamente, cria a impressão de que não há correntes críticas internas ao Islão e reforça a apropriação do Islão pela leitura "fundamentalista".

$\mathrm{Na}$ abordagem da questão central, também o enquadramento e montagem do tema são bastante significativos. Directamente após formular a pergunta "qual é, se ela existe, a relação entre terrorismo e religião?", logo os

islâmico, com base no estudo fundamentado dos arquivos dos tribunais, ou pela observação etnográfica dos tribunais em operação, e nos contextos mais diversos, constitui um dos passos mais importantes da superação do paradigma orientalista dum Islão cuja verdade e realidade se esgotava no estudo dos textos, sem atender à sua aplicação, e quanto muito, se restringia ao Médio Oriente árabe como Islão mais puro. Ver a título de exemplo Keddie e Baron (1991), Moors (1995, 1999), Hirsch (1998), Tucker, (1998), Meriwether (1999), Sonbol (2001, 2003), Sanday (2002), Peletz (2002), An-Na'im (2002), Kamali (2002), Pierce (2003), Rouse (2004).

${ }_{15}$ Ver, por todas, Shaheed (1994: 1011), Wadud (1999), Webb (2000) e Barlas (2002, 2004). 
autores respondem "de antemão à objecção" que prevêm citando "um inquérito fidedigno [que] dá a conhecer que em Maio de 2003 a acção de Usamah bin Laden é aprovada por grandes maiorias de muçulmanos (supõe-se que moderados, não terroristas) em vários países" (Gil e Tunhas, 2003: 195). Deixando de lado o facto de os termos do inquérito não formularem a pergunta nem permitirem ler a resposta como "aprovação" ou não da acção (que o texto faz supor referir-se aos atentados de 11 de Setembro), e menos ainda como significando que esta "aclamação" resulta especificamente da sua "garantia da vontade de aniquilamento do Ocidente e em particular dos EUA e de Israel" [poucas páginas após, o mesmo inquérito e a mesma resposta são novamente citados, mas agora já em comprovação de que "os feitos de Bin Laden são considerados excelentes" (206)], é particularmente de estranhar que os autores se permitam um duplo deslize. Com rigor, o que pode dizer-se é que o inquérito foi conduzido junto das populações de países de maioria muçulmana, pelo que a afirmação de que é aprovado por grandes maiorias de muçulmanos é já um pequeno deslize; pequeno, mas importante, porque é ele que permite o segundo deslize implícito: a noção de que essa "aprovação" (lembremos que é assim que os autores referem este resultado) de alguma forma reflecte o facto de serem muçulmanos. De expressão de opinião por inquiridos em países de maioria muçulmana, ela torna-se opinião de muçulmanos e de alguma forma expressão do seu Islão, assim relevante para pensar a questão da relação entre terrorismo e religião.

Chegando ao centro da questão, os autores afirmam peremptoriamente que a "leitura belicosa [do Corão] não constitui uma tolice fantasista nem uma forçagem mal intencionada de detractores" (195), proposição que fundamentam ao longo das sete páginas seguintes. Primeiro, e tautologicamente, refutando a "ficção de um Islão moderado e racionalista" veiculada por intelectuais ocidentais, acusados de má fé e "ódio a si” porque são omissos sobre essa mesma leitura belicosa que falta fundamentar. Depois, pela rejeição, como de igual má fé e maior ingenuidade, das leituras apologistas dos tradutores e comentaristas muçulmanos consultados, porque omissas sobre a mesma "obrigação da guerra", do anti-semitismo e da opressão da mulher, mais uma vez assumidos como islâmicos. A circularidade do argumento é aqui agravada pela selectividade das obras consultadas que, inexplicavelmente, não fazem referência a qualquer das inúmeras, autorizadas e reconhecidas contestações tradicionalistas, ou progressistas, de muçulmanos que lidam explícita e criticamente com essas questões. De resto, a fundamentação da caracterização belicosa e opressiva do Islão é avançada através de três pontos. Primeiro, a afirmação de que a contextualização apologética, sobre a qual se lança a suspeita de servir de estratégia dissimuladora, não é 
justificável à luz da universalidade pretendida para o texto (197-98). Proposta e refutação que se fazem sem qualquer referência aos princípios metodológicos de contextualização, ab-rogação, inter-relação, raciocínio por analogia e interpretação actualizadora consagrados nas ciências clássicas do Corão (von Denfer, 1994; Mérad, 1998) e hoje objecto de novos esforços de teorização e reformulação (Esack, 1997, 2002; Taji-Farouki, 2004). Segundo, através de uma leitura integrista do Corão, que se faz nos termos do modo integrista de ler o Corão: literal, descontextualizado, à margem das regras tradicionais de leitura e das leituras já consagradas. Lendo, particularmente, desta perspectiva, os temas da "guerra justa" e da hostilidade homicida frente aos cristãos e, particularmente, aos judeus (194), assim se chega à conclusão (para cuja sustentação temos apenas a análise dos temas citados, e nenhuma análise de qualquer outro aspecto do texto que permita quantificar ou relativizar a importância dos temas citados na economia textual do Corão) de que "Se o Corão possui um tema unificador, ele reside no combate por Alá, não menos do que na sua glorificação. A glorificação faz-se pelo combate" (202). Conclusão difícil de compatibilizar com uma percepção muçulmana do Corão, que se apoia, por exemplo, no facto de que o conceito preponderante e mais vezes repetido é o conceito de Justiça, por muitos reconhecido como talvez a mais completa definição do espírito do Islão; que uma das palavras mais repetidas no Livro, é a de "conhecimento" ou "sabedoria", que alguns vão ao ponto de chamar o primeiro dever islâmico de todo o muçulmano (Hanafi, apud Murphy 2002: 189); e de que o nome e atributo de Deus mais repetido no Corão é "O Misericordioso".

Além da questão das ciências da leitura e interpretação do Corão, há uma outra dimensão do problema descurada pelos autores. Dado que a ênfase recai sobre o sentido da leitura, e o efeito do texto traduzido em gesto, interessaria conhecer a tradição exegética (Ayub, 1984; Gätje, 1996; McAuliffe et al., 2003: 311-461), por um lado, e, por outro, os meios de transmissão oral do Corão, e o modo como ele é posto em uso nas escolas do Estado e nas madrassas e Universidades (Antoun, 1993; Lambeck, 1993; Houtsonen, 1994; Starrett, 1998; Brenner, 2000; McAuliffe, 2003), na cultura popular, pelos livros de quadradinhos para crianças (Douglas e Malti-Douglas, 1994), pelos pregadores nos sermões, pelas mulheres pregadoras e pelos ulemas em geral (Antoun, 1989; Gaffney, 1994; Kamalkhani, 1998: 47-70; Zaman, 2004). Acima de tudo, importaria conhecer o lugar, papel, função, e uso a que o Corão é submetido pelos muçulmanos no quotidiano. Poderíamos começar por lembrar que o Corão é escrito em árabe e, mais especificamente, em árabe clássico, impenetrável tanto para os não arabófonos (cerca de $80 \%$ dos muçulmanos do mundo) como para os árabes 
que possuam apenas uma cultura oral ou educação elementar nas versões vernaculares dos vários países. O árabe clássico do Corão, sendo língua viva, não é língua materna de ninguém (Haeri, 2003). Depois, a questão é a seguinte: a leitura/recitação do Corão pelos muçulmanos no quotidiano das orações é primeiro e antes de tudo o mais uma forma de comunhão com Deus através da enunciação da sua palavra, e essa comunhão passa, em primeira instância, ao lado do sentido das palavras. Religiosa e sociologicamente, o Corão é, acima de tudo, um texto recitado. Como Kristina Nelson (2001: xvi) concisamente explica: "o significado do Corão é expresso tanto pelo som como pela informação semântica. Por outras palavras, o Corão não é o Corão se não for ouvido", e "para muitos muçulmanos a recitação constitui a única forma de acesso ao Corão". Desde que, logo a partir da infância, começam a memorizar as suratas mais breves do Corão, os muçulmanos, com ou sem conhecimento linguístico do árabe, começam a "interiorizar os seus ritmos, padrões de som e dinâmica textual", iniciando uma relação com o Corão que não é, nem a natureza do texto o permitiria, a da leitura de uma narrativa linear (Sells, 1999: 11-12; Robinson, 1996: 9-24; Esack, 2002: 13-29). A audição do Corão pressupõe mesmo, segundo Hirschkind (2001), a adopção de práticas disciplinares para a educação de uma sensibilidade que se traduz numa disposição ética assumida na própria disposição corporal. E isto, para nem falar dos usos do texto físico do Corão em amuletos, curativos, etc.

Se esta dimensão da enunciação performativa na oração ritual, que indubitavelmente é a que mais de perto e intimamente constitui e determina a relação dos muçulmanos com o texto do Corão não é sequer referida pelos autores, a questão da leitura do texto enquanto texto religioso é igualmente ignorada por completo a favor de uma leitura legalista e prescritiva. Ora, esta, como já referi, é precisamente uma das diferenças entre a leitura islamista e as leituras tradicionais do Corão; e a que os autores fazem sua é a dos islamistas.

Num texto que prima pela completa ausência de familiaridade e referências não só aos comentaristas contemporâneos do Corão, mas aos intelectuais, reformistas, pensadores, exegetas e ideólogos muçulmanos contemporâneos, ${ }^{16}$ não pode deixar de ser significativo o facto de um único autor muçulmano, quase o único autor muçulmano mencionado, ser citado nada

\footnotetext{
${ }^{16}$ Essa falta de familiaridade está desde logo patente, por exemplo, na discussão do Mu'tazilismo (que os autores, inclusive, designam por Mu'talizismo [sic]), que é referido como "doutrina que desde há muito perdeu actualidade" (Gil e Tunhas, 2003: 196, n. 15), quando, pelo contrário, várias são as formas de diálogo com esta tradição no pensamento islâmico contemporâneo (cf. Martin et al., 1997; Mahdi, 2001).
} 
menos que seis vezes ao longo do livro: Abdelwahab Meddeb ${ }^{17}$. Ao problematizar o relevo dado pelos autores a Meddeb, não está em causa qualquer intuito de considerar Meddeb mais ou menos muçulmano que outros pela sua maior ou menor identificação com os valores ocidentais que advoga. A questão está na escolha de Meddeb de preferência a outros autores muçulmanos igualmente atentos à questão da relação entre a violência e os textos, mas que se situam numa relação com o Islão que não passa pelo secularismo, e particularmente que passa pelo confronto com a tradição jurídica do Islão ausente da abordagem de Meddeb.

Finalmente, dado o esbatimento da diferença entre Islão e islamismo ao longo do texto, assume particular importância a discussão pelos autores do que representa Osama para o muçulmano comum. E o que ele representa, é "a vingança" e "o gozo"; e a vingança, é "tanto contra o Ocidente como contra o próprio declínio muçulmano, conforme explicam os mais lúcidos pensadores e historiadores árabes e muçulmanos” (212). De que pensadores e historiadores se trata não é explicitado - quem surge de novo na nota mais próxima quanto à recusa da modernidade que explica esse declínio é ainda e sempre Meddeb, juntamente com Howayda Taha e Bernard Lewis. Mais uma vez, não parece ser importante referir a forma - indissociável do colonialismo e, depois, definitivamente comprometida, aos olhos dos muçulmanos, com os regimes secularistas do nacionalismo árabe pós-colonial - como tal modernidade chegou ao mundo islâmico. Aliás, todo o tratamento do Islão, dos muçulmanos e dos países árabes e muçulmanos decorre num vácuo histórico absoluto e, quando se fala das minorias islâmicas no Ocidente, atraídas por projectos identitários em torno do Islão, toda e qualquer referência às condições sociais e económicas destas comunidades, ao racismo e discriminação, e aos factores de hetero-definição que contribuem para esse auto-enclausuramento identitário, é simplesmente omitida. Tudo se explica, aparentemente, pelo facto de se ser muçulmano; a identidade muçulmana, nem coabita com outras, sendo a sua afirmação privilegiada situacionalmente em dados contextos e momentos, nem, pelos vistos, pode ou deve ser explicada como recurso simbólico: ela é antes, acima de tudo, e essencialmente religiosa. O integrismo, fundamentalismo, islamismo, explicados pelo Corão, não se situam historicamente por relação

17 Aliás, "o insuspeitado intelectual tunisino Abdelwahab Meddeb" (Gil e Tunhas, 2003: 20). Mas insuspeitado porquê? Por ser tunisino? Por ser intelectual? Ou porque, como desde logo o voltairiano título do seu livro sugere, o autor adopta uma posição declaradamente secularista? É, aliás, interessante que precisamente ao citar o apelo de Meddeb aos muçulmanos para que "se apropriem das luzes ocidentais", os autores se sintam na necessidade de justificar em nota que "Meddeb é um muçulmano convicto" $(177$, n. 27$) \mathfrak{x}$ curiosa nota esta: qual o critério ou autoridade que permite aos autores passarem atestado sobre a convicção religiosa de um muçulmano? 
ao falhanço dos projectos mobilizadores dos regimes nacionalistas seculares árabes, paradigmaticamente representados pelo Nasserismo, pelo que esse falhanço, portanto, não requer qualquer referência ao investimento estratégico da administração Eisenhower (Yaqub, 2004) para o assegurar (para já não dizer nada da doutrina Reagan no Afeganistão (Scott, 1996) e do seu papel no fomento dos Talibãs e, remotamente, das brigadas jihadistas incubadas na guerra anti-soviética. Assim, a "hostilidade aos Estados Unidos" é ("em parte" - a outra parte, embora seja pouco claro, seria talvez a "duvidosa moralidade pública dos Estados Unidos nas últimas décadas" a que os autores também se referem, mas que, e sem razão que se perceba, se declara não fazer parte do estudo proposto - assim, "em parte" mais acaba, portanto, por ser em todo) "conjuntural", por "focaliza[r] o ressentimento anti-ocidental" (216) - ressentimento que já sabemos ser afinal apenas expressão do ressentimento muçulmano perante o seu próprio declínio que resulta da sua recusa da modernidade.

Sociedades sem história. Textos sem vida. Religião sem comunidades interpretativas que a moldem. Mulheres passivas. Estou em crer que estamos menos em presença de má fé do que pura e simples ignorância dos autores. Primeiro, um provincianismo francês absoluto, que parece justificar que, num capítulo de 31 páginas sobre o Corão, seus sentidos e exegese pelos muçulmanos (que lembra serem um bilião e duzentos mil), a única referência a um autor muçulmano com qualquer peso sem ser em francês, ser a Abou el-Fadl, que os autores despacham numa linha (215 e n. 51) como generoso, mas pouco convincente e menos representativo ainda. No entanto, é Abou Fadl que é versado em direito islâmico e profundo conhecedor das tradições exegéticas dos textos islâmicos, cuja intervenção se efectua dentro mas ao revés da tradição (cf. Abou El-Fadl, 2001a, 2001b), ao contrário de Meddeb, escritor e crítico literário que se fica quase só pelas referências à cultura ocidental. Precisamente porque em diálogo com a tradição islâmica, a leitura de Abou el-Fadl (como de um An-Na'im, ou Mohammad Hashim Kamali ${ }^{18}$ ) requer uma aprendizagem e familiarização com a linguagem e tradição que os autores simplesmente ignoram ou de que, eurocentricamente, desdenham. Depois, um completo desconhecimento ou incompreensão dos debates, dos intervenientes, das linhas de força, dos temas e questões em torno dos quais actualmente se mobili-

${ }^{18}$ E não autores obscuros como o sheikh Al-Ouadah de Buraydah, cuja página islâmica na Internet os autores elegem aqui (sem qualquer preocupação com a sua efectiva representatividade, contextualização ou recepção) como um dos inúmeros exemplos de islamismo "relativamente moderado" (174-5) (sem que fiquemos a saber em que se distingue um "relativamente moderado" dum "moderado"). 
zam, e retraem, se encontram e se confrontam, em contextos específicos e determinados, as diferentes leituras, formas de organização, modos de vida e correntes de espiritualidade em conflito e contestação pela definição do Islão (Yamani, 1996; Afsaruddin, 1999; Mir-Housseini; Esposito e Voll, 2001; Cooke, 2001; Malti-Douglas, 2001; Saliba et al., 2002; Wolfe, 2002; O. Safi, 2003; Roberson, 2003; Abu-Rabi', 2004b; Sidiki, 2004; Sardar, 2004a; L. Safi, 2004).

Os autores de Impasses, na sua refutação das acusações de fundamentalismo e de "fanatismo" de George Bush, criticam os seus adversários pela incapacidade de reconhecer que a linguagem do religioso faz parte da tradição política americana, diferente da europeia, e que através dela se faz um jogo político em cujo discurso urge discriminar o que é linguagem e o que é argumento, o que é essencial e o que é acessório, sem o que se cai no simplismo do insulto político e da degradação do adversário representado em falso (Gil e Tunhas, 2003: 48-57). Curiosamente, aqui se revela a dupla cegueira dos autores. Por um lado, recusando-se a aceitar à letra a linguagem religiosa de Bush, pelo que ela efectivamente é, enquanto manifestação de um móbil religioso perfilhado na direita cristã que estrutura todo o seu discurso político, são eles, afinal, que acabam por representar em falso a posição de Bush. Por outro, na sua análise do Islão, revelam a mesma incapacidade crítica de atender à tradição, à linguagem e ao Islão enquanto recurso simbólico do xadrez político no mundo muçulmano de que acusam os seus adversários.

O Islão é uma religião em constante mutação pela negociação e contestação dos seus sentidos e definições por parte dos que dela se reclamam e a reivindicam em legitimação das suas visões e projectos. O "Islão" não tem outro sentido senão a "articulação" (Clifford, 2003) dos seus sentidos contemporâneos pela negociação dos sentidos anteriores através da reconfiguração dos elementos que em cada novo horizonte se afirmam acessórios ou intrínsecos. Mas que se afirmam como tal em resultado de negociações disputadas da interpretação do passado e do presente que revelam os traços dessa mesma história de disputa que assumem ou recusam. Em primeira e última instância, a unidade e continuidade do discurso residem no nome "Islão", enquanto signo de que se reivindicam os contestatários, e na referência ao "acto inaugural" da religião, cuja memória partilhada se desdobra em gesto de reprodução da comunidade ao longo dos tempos. Referência, portanto, não a um conteúdo marcado pela autenticidade originária, momento fundacional ou doutrina pura, a recuperar, mas enquanto gesto legitimador através do qual a comunidade a cada momento se reproduz (Sayyid, 2003: 42-44). O reconhecimento da natureza disputada do Islão implica 
que o historiador e cientista social que aborda as comunidades muçulmanas e o Islão não possa arrogar-se qualquer "noção normativa do Islão" (Brenner, 2000: 3), quer enquanto apoio para o reconhecimento do verdadeiro ou correcto Islão, quer, acima de tudo, em legitimação de uma qualquer intervenção no campo da disputa entre muçulmanos. E, complementarmente, que ele tenha de estar consciente de que é da natureza da contestação no terreno do religioso, e particularmente, no campo do direito e da tradição, que parceiros e adversários se reivindiquem representantes legítimos e intérpretes do verdadeiro Islão e procurem a deslegitimação por vezes da própria identificação religiosa do outro. Assim, o historiador ou cientista social não pode nunca limitar-se a proclamar acriticamente a veracidade ou autenticidade da tradição ou da interpretação por colagem a um discurso nativo que reflecte antes a arquitectura do poder que naturaliza um dado equilíbrio da polémica (cf. Asad, 2003: 218-223).

Para os muçulmanos, por sua vez, a recusa do essencialismo implica a rejeição dessa mesma polarização dicotómica em torno da reivindicação do verdadeiro Islão. O ponto de partida de uma plataforma progressista do Islão começa pela recusa do gesto de takfir que recusa ao outro o nome de muçulmano: muçulmano é todo aquele ou aquela que se reclame desse nome, o único juiz desta questão é Deus. Ao mesmo tempo, porém, uma plataforma progressista que se quer emancipatória não se rende nem abandona o direito e dever de batalhar pela promoção de uma visão crítica, igualitária, solidária e humanitária do Islão. Um passo no avanço desta visão, é o abandono pelos não muçulmanos - Estados, grupos de pressão, intelectuais, indivíduos - quer das suas visões essencialistas e ignorantemente condenatórias do Islão e dos muçulmanos, quer de um intervencionismo "condutor" da moderação, que, precisamente, cortam o espaço de manobra e legitimidade do debate interno.

\section{Referências Bibliográficas}

Abou El-Fadl, Khaled (2001a), The Conference of the Books. Lanham: University Press of America.

Abou El-Fadl, Khaled (2001b), Speaking in God's Name: Islamic Law, Authority and Women. Oxford: Oneworld.

Abou El-Fadl, Khaled (2003), "9/11 and the Muslim Transformation", in Mary L. Dudziak (org.), September 11 in History: A Watershed Moment?. Durham: Duke UP, 70-111.

Abu-Rabi', Ibrahim (2004a), "Introduction", in Montasser Al-Zayyat, The Road to Al-Qaeda. London: Pluto Press, 1-14. 
Abu-Rabi', Ibrahim M. (2004b), Contemporary Arab Thought: Studies in Post-1967 Arab Intellectual History. London: Pluto.

Afsaruddin, Asma (org.) (1999), Hermeneutics and Honour: Negotiating Female "Public" Space in Islamiclate Societies. Cambridge, Ma: HCMES.

An-Na'im, Abdullahi (org.) (2002), Islamic Family Law in a Changing World: A Global Resource Book. London: Zed Books.

Antoun, Richard T. (1989), Muslim Preacher in the Modern World: A Jordanian Case Study in Comparative Perspective. Princeton: Princeton UP.

Antoun, Richard T. (1993), "Themes and Symbols in the Religious Lesson: A Jordanian Case Study”, International Journal of Middle East Studies, 25, 607-624.

Asad, Talal (1993), Genealogies of Religion: Discipline and Reasons of Power in Christianity and Islam. Baltimore: Johns Hopkins UP.

Asad, Talal (2003), Formations of the Secular: Christianity, Islam, Modernity. Stanford: Stanford UP.

Ask, Karin; Tjomsland, Marit (orgs.) (1998), Women and Islamization: Contemporary Dimensions of Discourse on Gender Relations. Oxford: Berg.

Ayub, Mahmoud M. (1984), The Qur'an and its Interpreters, vol. 1. Albany: SUNY Press.

Ayubi, Nazih (1991), Political Islam: Religion and Politics in the Arab World. London: Routledge.

Aurélio, Diogo Pires (1996), "Tolerância/Intolerância”, in Enciclopédia Einaudi, vol. 22. Lisboa: IN-CM, 179-230.

Aurélio, Diogo Pires (1997), Um fio de nada: ensaio sobre a tolerância. Lisboa: Cosmos. Aurélio, Diogo Pires (1998), “O intolerável do ponto de vista da razão tolerante”, in João Lopes Alves (org.), Ética e o futuro da democracia. Lisboa: Colibri, 299-307. Aurélio, Diogo Pires (2003), "Muçulmanos, europeus”, Diário de Notícias, 21/6/2003. Aurélio, Diogo Pires (2004a), "Um véu de equívocos”, Diário de Notícias, 7/2/2004. Aurélio, Diogo Pires (2004b), "O vulcão”, Diário de Notícias, 10/4/2004.

Badran, Margot (1999), "Towards Islamic Feminisms: A Look at the Middle East”, in Asma Afsaruddin (org.), Hermeneutics and Honor. Cambridge, Ma: Harvard Centre for Middle Eastern Studies, 159-188.

Barlas, Asma (2002), "Believing Women" in Islam: Unreading Patriarchal Interpretations of the Qur'an. Austin: University of Texas Press.

Barlas, Asma (2004), “Amina Wadud's Hermeneutics of the Qur'an: Women Rereading Sacred Texts", in Suha Taji-Farouki (org.), Modern Muslim Intellectuals and the Qur'an. Oxford: Oxford UP, 97-123.

Brenner, Louis (2000), Controlling Knowledge: Religion, Power and Schooling in a West African Muslim Society. London: Hurst.

Carvalho, Henrique Martins de (1968), "Política externa portuguesa no Oriente", in Colóquios sobre as Províncias do Oriente. Lisboa: JIU-CEPS, II, 159-169. 
Carvel, John (2004), “Census Shows Muslims’ Plight”, Guardian, 12/10/2004.

Clifford, James (2003), On the Edges of Anthropology (Interviews). Chicago: Prickly Paradigm Press.

Cooke, Miriam (2001), Women Claim Islam: Creating Islamic Feminism through Literature. London: Routledge.

Cooper, John et al. (orgs.) (2000), Islam and Modernity: Muslim Intellectuals Respond. London: I.B. Tauris.

Daniel, Norman (1960), Islam and the West: The Making of an Image. Edinburgh: Edinburgh UP.

Denffer, Ahmad von (1994), 'Ulum al-Qur'an: An Introduction to the Sciences of the Qur'an. Leicester: Islamic Foundation.

Dias, Eduardo (1946), "Um Problema: O Islamismo e a sua penetração na África Negra”, Rumo, 6, 222-243.

Dias, Jorge et al. (1956), Missão de estudos étnicos das minorias étnicas do Ultramar Português. Relatório da Campanha de 1959. Confidencial. IANTT: AOS/CO/UL-37 pasta 2.

Douglas, Allen; Malti-Douglas, Fedwa (1994), Arab Comic Strips: Politics of an Emerging Mass Culture. Bloomington: Indiana UP.

Eisenstein, Zillah (2002), "Feminisms in the Aftermath of September 11", Social Text, 72(3), 79-99.

Esack, Farid (2002), The Qur'an: A short introduction. Oxford: Oneworld.

Esack, Farid (1997), Qur'an, Liberation and Pluralism: An Islamic Perspective of Interreligious Solidarity Against Oppression. Oxford: Oneworld.

Esposito, John; Voll, John (2001), Makers of Contemporary Islam. New York: OUP.

Euben, Roxanne L. (1999), Enemy in the Mirror: Islamic Fundamentalism and the Limits of Modern Rationalism. Princeton: Princeton UP.

Ezzat, Heba Raouf; Abdalla, Ahmed Mohammed (2004), "Towards an Islamically Democratic Secularism”, in Valérie Amiraux et al., Faith and Secularism. London: British Council, 32-54.

Fawzi, Essam (2004), "Muslim Personal Status Law in Egypt: the Current Situation and Possibilities of Reform through Internal Initiatives”, in Lynn Welchman (org.), Women's Rights E Islamic Family Law: Perspectives on Reform. London: Zed Books, 15-94.

Fernea, Elizabeth Warnock (1998), In Search of Islamic Feminism: One Woman's Global Journey. New York: Doubleday.

Franklin, António G. de Sousa (1956), A ameaça islâmica na Guiné Portuguesa. Lisboa.

Gaffner, Patrick D. (1994), Prophet's Pulpit: Islamic Preaching in Contemporary Egypt. Berkeley: University of California Press.

Gallo, Donato (1989), Antropologia e colonialismo: O saber português. Lisboa: ER-Heptágono.

Gätje, Helmut (1996), The Qur'an and its Exegesis. Oxford: Oneworld. 
Gil, Fernando; Tunhas, Paulo; Cohn, Danièle (2003), Impasses, seguido de Coisas vistas, coisas ouvidas. Mem Martins: Europa-América.

Gonçalves, José Júlio (1958a), “O Islamismo na Guiné Portuguesa”, Boletim Cultural da Guiné Portuguesa, 52, 397-470.

Gonçalves, José Júlio (1958b), “As 'elites’ no Ultramar Português”, in Colóquios de Política Ultramarina Internacionalmente Relevante. Lisboa: JIU-CEPS: 87-110.

Gonçalves, José Júlio (1958c), O mundo árabo-islâmico e o Ultramar Português. Lisboa: MU-JIU-CEPS [ $2^{a}$ ed. 1962].

Gonçalves, José Júlio (1960), O Islamismo através dos números. Lisboa: AGU.

Gonçalves, José Júlio (1961), O Islamismo na Guiné Portuguesa (ensaio sócio-missionológico). Lisboa.

Haeri, Niloofar (2003), Sacred Language, Ordinary People: Dilemmas of Culture and Politics in Egypt. Cambridge: Cambridge UP.

Hewer, Chris (2003), "The Multireligious Multicultural Society: A Case Study of Birmingham, England”, in Viggo Mortensen (org.), Theology and the Religions: A Dialogue. Grand Rapids, MI: William Erdmans, 67-71.

Hirsch, Susan E. (1998), Pronouncing E Preserving: Gender and the Discourse of Dispute in an African Court. Chicago: Chicago UP.

Hirschkind, Charles (2001), "The Ethics of Listening: Cassette Sermon Audition in Contemporary Cairo", American Ethnologist, 28(3), 623-649.

Hirschkind, Charles; Mahmood, Saba (2002), "Feminism, the Taliban, and Politics of Counter-Insurgency”, Anthropological Quarterly, 75(2), 339-354.

Hoodfar, Homa (2001), "The Veil in Their Minds and on Our Heads: Veiling Practices and Muslim Women”, in Elizabeth A. Castelli (org.), Women, Gender, Religion: A Reader. Basingstoke: Palgrave, 420-426.

Houtsonen, Jarmo (1994), “Traditional Qur'anic Education in a Southern Moroccan Village”, International Journal of Middle East Studies, 26, 489-500.

Huntington, Samuel (1993), "The Clash of Civilizations?”, Foreign Affairs, 72, 22-49.

Huntington, Samuel (1996), The Clash of Civilizations and the Remaking of World Order. New York: Simon \& Schuster.

Inayatullah, Sohail; Boxwell, Gail (orgs.), Islam, Postmodernism and Other Futures: A Ziauddin Sardar Reader. London: Pluto Press.

Kamali, Mohammad Hashim (2002), Freedom, Equality and Justice in Islam. Cambridge: Islamic Texts Society.

Kamalkhani, Zahra (1998), Women's Islam: Religious Practice among Women in Today's Iran. London: KPI.

Keddie, Nikki; Baron, Beth (orgs.) (1991), Women in Middle Eastern History: Shifting Boundaries in Sex and Gender. New Haven: Yale UP.

Kepel, Gilles (2004), The War for Muslim Minds: Islam and the West. Cambridge, Ma: Harvard UP. 
Lambeck, Michael (1993), Knowledge and Practice in Mayotte: Local Discourses of Islam, Sorcery and Spirit Possession. Toronto: UTP.

MacAuliffe, Jane Dammen (2003), "Disparity and Context: Teaching Quranic Studies in North America”, in Brannon M. Wheeler (org.), Teaching Islam. New York: OUP, 94-107.

MacAuliffe, Jane Dammen et al. (2003), With Reverence for the Word: Medieval Scriptural Exegesis in Judaism, Christianity, and Islam. New York: OUP.

Mahdi, Muhsin (2001), “The Rational Tradition in Islam”, in Farhad Daftari (org.), Intellectual Traditions in Islam. London: I.B. Tauris, 43-65.

Majid, Anouar (2000), Unveiling Traditions: Postcolonial Islam in a Polycentric World. Durham: Duke UP.

Malti-Douglas, Fedwa (2001), Medicines of the Soul: Female Bodies and Sacred Geographies in a Transnational Islam. Berkeley: University of California Press.

Margarido, Alfredo (1991), "O Islamismo face ao Ocidente e mais particularmente do Médio Oriente”, Finisterra, 6, 31-50.

Margarido, Alfredo (2003), "Do Islão teológico ao Islão dos atentados”, Finisterra, 47/48, 13-30.

Martin, Richard C. et al. (1997), Defenders of Reason in Islam: Mu'tazilism from Medieval School to Modern Symbol. Oxford: Oneworld.

Mérad, Ali (1998), L'Exégèse coranique. Paris: PUF.

Meriwether, Margaret L. (1999), The Kin Who Count: Family and Society in Ottoman Aleppo, 1770-1840. Austin: University of Texas Press.

Mir-Hosseini, Ziba (1999), Islam and Gender: The Religious Debate in Contemporary Iran. Princeton: Princeton UP.

Mirsepassi, Ali (2000), Intellectual Discourse and the Politics of Modernization: Negotiating Modernity in Iran. Cambridge: Cambridge UP.

Monteiro, Fernando Amaro (1975), Carta aberta aos muçulmanos de Moçambique independente. Lisboa: Cadernos Pensamento Político.

Monteiro, Fernando Amaro (1993), O Islão, o poder e a guerra (Moçambique 1964-1974). Porto: Universidade Portucalense.

Moors, Annelies (1995), Women, Property and Islam: Palestinian experiences 1920-1990. Cambridge: Cambridge UP.

Moors, Annelies (1999), "Debating Islamic Family Law: Legal Texts and Social Practices”, in Margaret Meriwether; Judith Tucker (orgs.), A Social History of Women and Gender in the Modern Middle East. Boulder: Westview Press, 142-175.

Moreira, Adriano (1955), "A Conferência de Bandung e a missão de Portugal”, Boletim da Sociedade de Geografia de Lisboa, Abr.-Jun.,159-172.

Moreira, Adriano (1956a), Política ultramarina. Lisboa: MU-JIU-CEPS.

Moreira, Adriano (1956b), "As elites das províncias portuguesas de indigenato (Guiné, Angola, Moçambique)”, Garcia de Orta, 6(2), 159-189. 
Moreira, Adriano (1963), "De Bandung ao Cairo”, in A. Moreira, Ensaios. Lisboa: JIU-CEPS, 63-78 [11958].

Moreira, Adriano (2003), "Prefácio", in Maria do Céu Pinto, "Infiéis na Terra do Islão": Os Estados Unidos, o Médio Oriente e o Islão. Lisboa: Fundação Calouste Gulbenkian, 11-14.

Moreira, Porfírio Gomes (1967), “Apontamentos sobre o Islamismo”. IANTT: SCCIM Cx.71.

Mota, Avelino Teixeira da (1954), Guiné Portuguesa, 2 vols. Lisboa: AGU.

Muñoz, Gema Martin (2002), “Islam's Women under Western Eyes” (www.opendemocracy. net).

Murphy, Caryle (2002), Passion for Islam. New York: Scribner.

Naipaul, V. S. (1982), Among the Believers: An Islamic Journey. London: Penguin Books.

Nelson, Kristina (2001), The Art of Reciting the Qur'an. Cairo: The American University in Cairo Press.

Neto, João Baptista Nunes Pereira (1968), Colóquios sobre as Províncias do Oriente. Lisboa: JIU-CEPS, 199-244.

Ouis, Soumaya Pernilla (2003), "Global Environmental Relations: An Islamic Perspective”, The Muslim Lawyer, 4(1) (http://www.aml.org.uk/journal/).

Peletz, Micahel G. (2002), Islamic Modern: Religious Courts and Cultural Politics in Malaysia. Princeton: Princeton UP.

Pierce, Leslie (2003), Morality Tales: Law and Gender in the Ottoman Court of Aintab. Berkeley: University of California Press.

Ramadan, Tariq (2004), Western Muslims and the Future of Islam. New York: Oxford UP.

Rego, António da Silva (1939), "O Islamismo”, in A. da Silva Rego, O Oriente e o Ocidente. Ensaios. Lisboa, s.e., 42-59.

Rego, António da Silva (1960a), "Alguns problemas sociológico-missionários da África Negra”, in Missão para o estudo da missionologia africana. Relatório da Campanba de 1959. Confidencial. IANTT: AOS/CO/UL-37.

Rego, António da Silva (1960b), Alguns problemas sociológico-missionários da África Negra. Lisboa: JIU-CEPS.

Rego, Lobiano do (1959), Pátria morena: à vista da maior epopeia lusíada. Macieira de Cambra: LAIN.

Rego, Lobiano do (1965), Apocalipse de Sagres. s.l.: LAIN.

Rego, Lobiano do (1966), A “declaração sobre liberdade religiosa” no tempo e espaço da nação portuguesa. Comentário à primeira parte. Braga: Pax.

Rego, Lobiano do (1969), O progresso religioso dos povos. Religião ou religiões?. s.l.: LAIN.

Rego, Lobiano do (1970), “Deus ou Alá?”. IANTT: SCCIM Cx. 384, fl.382.

Roberson, B. A. (2003), Shaping the Current Islamic Reformation. London: Frank Cass. 
Robinson, Neal (1979), Discovering the Qur'an: A Contemporary Approach to a Veiled Text. London: SCM Press.

Rouse, Carolyn Moxley (2004), Engaged Surrender: African American Women and Islam. Berkeley: University of California Press.

Sadiki, Larbi (2004), The Search for Arab Democracy: Discourses and Counter-Discourses. Columbia: Columbia UP.

Safi, Louay (2004), Tensions and Transitions in the Muslim World. Dallas: University Press of America.

Safi, Omid (org.) (2003), Progressive Muslims: On Justice, Gender, and Pluralism. Oxford: Oneworld.

Said, Edward (1981), Covering Islam: How the Media and the Experts Determine How We See the Rest of the World. London: Routledge \& Kegan Paul.

Said, Edward (2000), Reflections on Exile and Other Literary and Cultural Essays. London: Granta.

Saliba, Therese et al. (org.), Gender, Politics, and Islam. Chicago: University of Chicago Press.

Sardar, Ziauddin (org.) (1991), Islam and the Future, Futures 23(3) (número especial).

Sardar, Ziauddin (2004a), Desperately Seeking Paradise: Journeys of a Sceptical Muslim. London: Granta.

Sardar, Ziauddin (2004b), “Can Islam Change?”, New Statesman, 13/9/2004, 24-27.

Sardar, Ziauddin (2004c), Beyond Difference: Cultural Relations in the New Century. London: British Council.

Sayyid, S. (2003), A Fundamental Fear: Eurocentrism and the Emergence of Islamism. London: Zed Books.

Sayyid, S. (no prelo), "Mirror, Mirror: Western Democrats, Oriental Despots“, Ethnopolitics.

Scott, James M. (1996), Deciding to Intervene: The Reagan Doctrine and American Foreign Policy. Durham: Duke UP.

Scruton, Roger (2002), The West and the Rest: Globalization and the Terrorist Threat. London: Continuum.

Sanday, Peggy Reeves (2002), Women at the Centre: Life in a Modern Matriarchy. Ithaca: Cornell UP.

Sells, Michael (1999), Approaching the Qur'an: The Early Revelations. Ashgon: White Cloud Press.

Shaheed, Farida (1994), "Controlled or Autonomous: Identity and the Experience of the Network, Women Living under Muslim Laws”, Signs, 19(4), 997-1019.

Simões, Francisco da Rocha (1968), "Importância militar das províncias ultramarinas", in Colóquios sobre as Províncias do Oriente. Lisboa: JIU-CEPS, I, 345-371.

Sonbol, Amira El-Azhari (1999), "Rethinking Women and Islam”, in Yvonne Yazbeck Haddad; John Esposito (orgs.), Daughters of Abraham: Feminist Thought in Judaism, Christianity, and Islam. Gainesville: University Press of Florida, 108-146. 
Sonbol, Amira El-Azhar (2003), Women of Jordan: Islam, Labor, E the Law. Syracuse: Syracuse UP.

Starrett, Gregory (1998), Putting Islam to Work: Education, Politics, and Religious Transformation in Egypt. Berkeley: University of California Press.

Taji-Farouki, Suha (org.) (2004), Modern Muslim Intellectuals and the Qur'an. Oxford: Oxford UP.

Tucker, Judith (1998), In the House of the Law: Gender and Islamic Law in Ottoman Syria and Palestine. Berkeley: University of California Press.

Vakil, AbdoolKarim (2000), "Eça e o Islão: Questões do Oriente/Questões do Ocidente”, Camões. Revista de Letras e Culturas Lusófonas, 9-10, 75-94.

Vakil, AbdoolKarim (2003a), "Questões inacabadas: Colonialismo, Islão e portugalidade”, in Margarida Calafate Ribeiro; Ana Paula Ferreira (orgs.), Fantasmas e fantasias imperiais no imaginário português contemporâneo. Porto: Campo das Letras, 255-294.

Vakil, AbdoolKarim (2003b), “O 'Portugal islâmico', o 'Portugal multicultural' e os muçulmanos portugueses: História, memória e cidadania na construção de novas identidades", in Guilhermina Mota (org.), Minorias étnicas e religiosas em Portugal: História e actualidade. Coimbra: IHES-FLUC, 409-451.

Vakil, AbdoolKarim (no prelo), "Comunidade islâmica em Portugal”, in Fernando Cristovão (org.), Dicionário temático da lusofonia. Lisboa: Instituto Camões.

Wadud, Amina (1999), Qur'an and Woman: Rereading the Sacred Text from a Woman's Perspective. New York: Oxford UP [11992].

Webb, Gisela (org.) (2000), Windows of Faith: Muslim Women Scholar-Activists in North America. Syracuse: Syracuse UP.

Wolfe, Michael (org.) (2002), Taking Back Islam: American Muslims Reclaim Their Faith. s.l.: Beliefnet.

Yamami, Mai (org.) (1996), Feminism E Islam: Legal and Literary Perspectives. New York: New York UP.

Yaqub, Salim (2004), Containing Arab Nationalism: The Eisenhower Doctrine and the Middle East. Chapel Hill: The University of North Carolina Press.

Zaman, Muhammad Qasim (2004), The Ulama in Contemporary Islam: Custodians of Change. Princeton: Princeton UP. 